Папп В.В, Бошота Н.В.

\title{
ФІСКАЛЬНА РОЛЬ ПОДАТКОВИХ НАДХОДЖЕНЬ ТУРИСТИЧНИХ ПІДПРИСМСТВ КРАЇНИ
}

\begin{abstract}
Стаття присвячена дослідженню фіскальної ролі податкових надходжень туристичних підприємств краӥни. Виокремлено дві основні протидіючі функиії оподаткування: фіскальну та регулюючу, а також проаналізовано їх вплив на наповнення бюджетів різних рівнів. Проаналізовано надходження туристичного збору до місиевих бюджетів, а також збір податкових платежів від діяльності туристичних суб'єктів. Окреслено можливі тенденції до збільшення фіскальної ефективності та поліпшення фінансового забезпечення справляння податків туристичних підприємств. Доведено важливість фіскальної ролі податкових надходжень у туристичному бізнесі.
\end{abstract}

Ключові слова: туризм, податки, наповнення бюджету, податкова політика, система оподаткування, дохід, місиевий бюджет.

Постановка проблеми. Фінансова політика країни в даний період зосереджена задля значного наповнення як державного, так i місцевих бюджетів, але основним джерелом надходження залишаються податки, рівень яких $\epsilon$ недостатнім для фінансової стабілізації країни. Податки $€$ основним інструментом державної політики країни, що допомагає покрити державні видатки та здійснити фіскальну та розподільчу функції в економіці. Проте нестабільність дохідної частини бюджетів всіх рівнів спричинена відсутністю ефективного механізму перерозподілу доходів, нерівномірністю розвитку регіонів. Особливо, ця нерівність простежується у туристичному секторі економіки, фіскальна роль надходжень яких недостатньо збалансовує національні інтереси і потреби населення.

Аналіз останніх досліджень і публікацій. Сферою дослідження фіскальної ролі податків в Україні займалась значна кількість науковців серед яких: Л. Синявська [7], К. Маліновська [3], А. Гера [3], Н. Власюк [1], В. Андрущенко, В. Опарін, О. Василик та інші. Вплив податкових надходжень туристичної сфери досліджувались в роботах: Т. Момонта [4], А. Діденка [2], Т. Томнюка [9], П. Мельника, Г. Старостенка та В. Вітлінського. Аналізом та оцінкою рівня податкової системи займалися такі вітчизняні вчені: В. Вітлинський, Ю. Іванов. Проте залишається невирішеним питання підвищення ефективності фіскальної ролі податкових

(C) Папп Василь Васильович, д.е.н., проф., професор кафедри туризму i рекреації, Мукачівський державний університет, м. Мукачево

Бошота Неля Василівна, к.е.н., старший викладач кафедри фінансів, Мукачівський державний університет, м. Мукачево надхожень туристичних підприємств країни, якому присвячена ця стаття.

Формулювання цілей статті. Метою дослідження $є$ визначення фіскальної ролі податкових надходжень туристичних підприємств країни та виявлення можливих тенденцій до збільшення фіскальної ефективності.

Опис основного матеріалу дослідження. Туризм $\epsilon$ важливим джерелом податкових надходжень для місцевого бюджету, оскільки туристичне підприємство належить до однієї 3 провідних галузей розвитку економіки нашої країни. Він виконує функції налагодження торговельно-економічних відносин, забезпечує надходження іноземної валюти від провадження діяльності, а зростання доходів туристичних підприємств примножує рівень податкових надходжень до бюджетів.

На початку XX ст. в економіці було виділенно дві основні протидіючі функції оподаткування: фіскальна та регулююча. За допомогою регулюючої функції створюються механізми, що забезпечують збалансованість корпоративних, особистих та загальнодержавних економічних інтересів, а завдяки фіскальній функції оподаткування задовольняються загальнонаціональні потреби. Тобто, фіскальна функція податків полягає у стягненні коштів у розпорядження держави та формуванні центральних фінансових ресурсів для забезпечення виконання функцій держави [7].

На думку К. О. Маліновської та А. С. Гери, з підвищенням соціального значення податків та їх ролі у суспільстві і житті громадян фіскальна функція стала існувати поряд із соціальною, дія якої полягає у перерозподілі доходів між різними соціальними групами населення [3, с.428].

Вважаємо, що фіскальна функція за своєю природою $є$ взаємнодоповнюючою до регулюю- 
чої функції. Якщо перерозподіл фінансових надходжень буде здійснено правильно, то акумулювання коштів різних рівнів будуть наповнювати бюджет ефективно. Проте фіскальна функція податкової системи на даному етапі економічного розвитку залишається недостатньо дієвою. В першу чергу, ця тенденція простежується у недосконалості фіскальної ролі податкових надходжень туристичних підприємств країни.

Оподаткування туристичного підприємства має істотний вплив на загальний добробут України, оскільки зменшується бюджетне обмеження і задовольняється дефіцитом, в ході якого отриманий дохід може використовуватися на забезпечення суспільних благ. Доходи бюджетів створюються за рахунок податків від фізичних та юридичних осіб, що є суб' єктами на туристичному ринку, та інших обов'язкових платежів, що встановлені законодавством. Національний дохід від активізації туризму зростає за рахунок оплати туристами послуг туроператорів та турагентів, екскурсоводів, транспортного, ресторанного та готельного сектору економіки, споживання товарів та послуг [9, с.115]. Основним Законом України, що регулює діяльність туристичних підприємств, $є$ Закон України «Про туризм» від 15.09.1995 р. № 324/95-ВР зі змінами та доповненнями. Згідно ст. 5 цього Закону учасниками відносин, що виникають при здійсненні туристичної діяльності, $є$ юридичні та фізичні особи, які створюють туристичний продукт або надають туристичні послуги. До суб'єктів належать туристичні оператори та туристичні агенти.

За даними Державної фіскальної служби України та Міністерства економічного розвитку і торгівлі України обсяг надходжень від сплати туристичного збору у 2016 році склав 54,1 млн грн., що на 45,7 \% більше ніж у 2015 році. При цьому його обсяг у 2015 році у порівнянні з 2014 роком зріс на 49,9\%, про що свідчать дані таблиці (табл. 1).

Таблиця 1

Надходження туристичного збору до місцевих бюджетів за 2014-2016 pp. [5]

\begin{tabular}{|c|l|c|c|c|c|c|}
\hline $\begin{array}{c}\text { Код } \\
\text { регіону }\end{array}$ & \multicolumn{1}{|c|}{ Назва області } & $\mathbf{2 0 1 4}$ & $\mathbf{2 0 1 5}$ & $\mathbf{2 0 1 6}$ & Частка, \% & $\begin{array}{c}\text { Приріст } \\
\mathbf{2 0 1 6 / 2 0 1 5}\end{array}$ \\
\hline 1 & АР Крим & 482,6 & 0 & - & - & - \\
\hline 2 & Вінницька & 181,1 & 209,6 & 310,4 & 0,6 & $\uparrow 48,1 \%$ \\
\hline 3 & Волинська & 200,7 & 324,2 & 373,4 & 0,7 & $\uparrow 15,2 \%$ \\
\hline 4 & Дніпропетровська & 877,4 & 1289,4 & 1749,9 & 3,2 & $\uparrow 35,7 \%$ \\
\hline 5 & Донецька & 846,1 & 669,1 & 914,3 & 1,7 & $\uparrow 36,6 \%$ \\
\hline 6 & Житомирська & 169,0 & 225,3 & 349,4 & 0,6 & $\uparrow 55,1 \%$ \\
\hline 7 & Закарпатська & 930,4 & 1527,2 & 2199,1 & 4,1 & $\uparrow 44,0 \%$ \\
\hline 8 & Запорізька & 1410,8 & 1565,3 & 2070,8 & 3,8 & $\uparrow 32,3 \%$ \\
\hline 9 & Івано-Франківська & 946,8 & 1578,5 & 2292,8 & 4,2 & $\uparrow 45,3 \%$ \\
\hline 10 & Київська & 682,4 & 862,5 & 1247,9 & 2,3 & $\uparrow 44,7 \%$ \\
\hline 11 & Кіровоградська & 65,7 & 92,3 & 167,9 & 0,3 & $\uparrow 81,9 \%$ \\
\hline 12 & Луганська & 109,4 & 47,7 & 102,7 & 0,2 & $\uparrow 115,3 \%$ \\
\hline 13 & Львівська & 3569,8 & 5915,0 & 8418,5 & 15,6 & $\uparrow 42,3 \%$ \\
\hline 14 & Миколаївська & 457,5 & 753,1 & 1155,3 & 2,1 & $\uparrow 53,4 \%$ \\
\hline 15 & Одеська & 2725,3 & 4865,2 & 7336,3 & 13,6 & $\uparrow 50,8 \%$ \\
\hline 16 & Полтавська & 313,4 & 449,2 & 717,1 & 1,3 & $\uparrow 59,7 \%$ \\
\hline 17 & Рівненська & 127,2 & 170,2 & 266,5 & 0,5 & $\uparrow 56,6 \%$ \\
\hline 18 & Сумська & 130,5 & 161,6 & 227,6 & 0,4 & $\uparrow 40,8 \%$ \\
\hline 19 & Тернопільська & 128,7 & 161,4 & 240,0 & 0,4 & $\uparrow 48,7 \%$ \\
\hline 20 & Харківська & 887,8 & 1081,5 & 1780,5 & 3,3 & $\uparrow 64,6 \%$ \\
\hline 21 & Херсонська & 793,2 & 1074,7 & 1888,4 & 3,5 & $\uparrow 75,7 \%$ \\
\hline 22 & Хмельницька & 207,8 & 303,1 & 465,7 & 0,9 & $\uparrow 53,7 \%$ \\
\hline 23 & Черкаська & 271,1 & 310,9 & 409,5 & 0,8 & $\uparrow 31,7 \%$ \\
\hline 24 & Чернівецька & 228,2 & 244,1 & 318,6 & 0,6 & $\uparrow 30,5 \%$ \\
\hline 25 & Чернігівська & 154,8 & 207,8 & 311,9 & 0,6 & $\uparrow 50,1 \%$ \\
\hline 26 & м. Київ & 5788,0 & 9779,0 & 14706,6 & 27,2 & $\uparrow 50,4 \%$ \\
\hline 27 & м. Севастополь & 58,5 & 0 & - & - & - \\
\hline 28 & Центральний офіс & 2022,6 & 3257,9 & 4073,6 & 7,5 & $\uparrow 25,0 \%$ \\
\hline Всього & & 24766,7 & 37126,1 & 54094,8 & 100,0 & $\uparrow 45,7 \%$ \\
\hline
\end{tabular}


По кожній із аналізованих областей відбувається значне зростання надходжень до місцевих бюджетів (крім окупованих територій). Проте, найбільша частка сплаченого туристичного збору в 2016 році припала на: Київ $27,2 \%$, Львівську область - 15,6\%, Одеську область - 13,6\%.

Ефективність оподаткування залежить від побудови механізму справляння кожного податку зокрема і податкової системи загалом
[1, с.69]. За даними Державної фіскальної служби України та Міністерства економічного розвитку i торгівлі України обсяг діяльності туристичних операторів та агентів щороку зростає, що свідчить про підвищення ролі туристичних підприємств на ринку туризму, $\mathrm{i}$, як наслідок, збільшуються податкові надходження до різних рівнів бюджетів країни (табл.2).

Діяльність туристичних операторів та агенств за 2014-2016 pp. [5]

\begin{tabular}{|c|c|c|c|c|}
\hline \multirow{2}{*}{ Збір податкових платежів } & $2014 \mathrm{p}$. & $2015 \mathrm{p}$. & $2016 \mathrm{p}$. & \multirow{2}{*}{$\begin{array}{c}\text { Порівняння } \\
2016 / 2015\end{array}$} \\
\hline & тис. грн & тис. грн & тис. грн & \\
\hline \multicolumn{5}{|c|}{ Діяльність туристичних операторів } \\
\hline Юридичні особи & 108511,4 & 133171 & 175356,5 & $\uparrow 31,7 \%$ \\
\hline \multicolumn{5}{|l|}{ Діяльність туристичних агентств } \\
\hline Юридичні особи & 64350,4 & 71179,5 & 80413,7 & $\uparrow 13 \%$ \\
\hline Фізичні особи - підприємці & 19170,8 & 23857,6 & 38881,4 & $\uparrow 63 \%$ \\
\hline
\end{tabular}

За даними таблиці 2 бачимо, що відбувається щорічне зростання від діяльності як туристичних агенств, так і туристичних операторів зі зборів податкових платежів, адже зростання за останній аналізований період варіює від 13 до 63\%, що є позитивним фактором підвищення наповнення бюджету.

Проте, зважаючи на сучасну економічну ситуацію, цього $є$ недостатньо аби фіскальна роль податкових надходжень досягла абсолютного виконання.

Податкові доходи держави від туризму формуються у результаті оподаткування суб'єктів туристичної діяльності та супутніх їй сфер прибутковими податками (податком на прибуток, податком на доходи фізичних осіб, єдиним податком) та непрямими податками (акцизним податком та податком на додану вартість) [9, с.115].

Особливості туристичної галузі випливають із специфічних властивостей послуг, що надаються туристичними підприємствами та організаціями [8].

На думку Діденко А.В., економічний аналіз класифікує податки, що застосовуються в туризмі, наступним чином: загальні податки, спеціальні виправдані податки і спеціальні необгрунтовані податки [2].

Об'єктом оподаткування податком на прибуток $є$ прибуток туристичного підприємства iз джерелом походження 3 України та за іiі межами, який визначається шляхом коригування фінансового результату до оподаткування (прибутку або збитку), визначеного у звітності підприємства, відповідно до національних діючих стандартів (ПБО або МСФЗ), які виникають згідно 3 положеннями Податкового кодексу.

Особливий порядок оподаткування ПДВ туристичної діяльності, згідно зі ст. 207 Податкового кодексу, обумовлено специфікою формування тур продукту - закупівлі послуг різних осіб для формування турпродукту, причому переважна більшість цих осіб може не бути платниками ПДВ. Якщо базою оподаткування туроператора $\epsilon$ винагорода, то іiі визначають як різницю між вартістю поставленого турпродукту (турпослуги) і сумою витрат, понесених туроператором внаслідок придбання (створення) турпродукту (турпослуги) [6].

Поширеними інструментами стимулювання розвитку туризму в світі $\epsilon$ : надання прямої фінансової підтримки, кредитування на пільгових умовах, надання в оренду земельних ділянок під будівництво готельних комплексів на довготривалий термін за символічну плату, податкові стимули. Іншими податковими стимулами, що застосовуються у високорозвинених туристичних країнах $\epsilon$ : застосування знижених ставок ПДВ та податку на прибуток, звільнення від оподаткування, застосування методів прискореної амортизації щодо інвестицій у туризмі, звільнення від оподаткування на визначений термін (податкові канікули) [9, с.116].

Усі ці стимули допоможуть у залученні в туристичний бізнес зовнішніх інвестицій у розвитку галузі, що $\epsilon$ так необхідні для стабілізації податкових надходжень. 
Єдиним податковим стимулом в Україні, що передбачений Податковим кодексом України та спрямованим на розвиток готельного сектору як складової туристичної інфраструктури України, $\epsilon$ тимчасове звільнення від оподаткування прибутку суб'єкта господарської діяльності, отриманого від надання готельних послуг, що діятиме до 1 січня 2020 року [9, с.116].

Також туристичні оператори, як і туристичні агенти можуть провадити свою діяльність як платники єдиного податку, або знаходитись на повній системі оподаткування. За п. 292.1 ст. 292 Податкового кодексу України доходом платника єдиного податку туристичного підприємства $\epsilon$ дохід, отриманий протягом податкового періоду в грошовій формі, матеріальній або нематеріальній, тобто доходом $\epsilon$ розмір отриманої винагороди, яка обчислюється за сумарним підсумком на місяць, квартал чи рік [6].

Саме тому, зважаючи на все вищезазначене, тенденціями до збільшення фіскальної ефективності та поліпшення фінансового забезпечення справляння податків $\epsilon$ :

- правильне планування i прогнозування надходжень від податків при його перерозподілі, яке сприятиме створенню комфортного податкового середовища функціонування туристичного підприємства, пришвидшить відтворювальні процеси та зміцнить податкових потенціал місцевих органів влади;

- максимальне зниження рівня тіньової економіки податкової системи 3 усуненням іiі наслідків, що допоможе вчасно наповнювати державний та місцеві бюджети, а також усунення дисбалансу між податковими надходженнями та видатками. Перш за все, це стосується застосування податкової ставки за один день надання туристичних послуг підприємствами, адже наразі ці послуги не враховуються для фіскальної результативності і, як наслідок, занижує вартість надання послуг;

- покращення діючої системи доходів бюджетів різних рівнів за рахунок поліпшення функціонування діяльності туристичних підприємств та за механізму розвитку фіскальних резервів, враховуючи потенціал окремого туристичного регіону або території надання туристичних послуг із реальними інструментами впливу на платників податків;

- вдосконалення діючої системи оподаткування туристичних підприємств шляхом максимізації надходжень, мінімізації видатків на адміністрування та підвищення еластичності податкового механізму. Цей шлях $є$ можливим покращенням за введенням в дію певних нових туристичних податків або відновлення існуючих. Наприклад, важливим $є$ екологічний податок, який сплачують туристичні підприємства, але його рівень $\epsilon$ досить низьким, саме тому законодавча база потребує зростання питомої ваги зазначених податків для наповнення місцевого бюджету;

- залучення іноземних інвестицій в розвиток туристичного бізнесу країни, що дасть додаткові стимули для розвитку туристичних підприємств, які активізують економічне зростання податкових надходжень до бюджетів різних рівнів.

Висновки i перспективи подальших досліджень. Складовою частиною економіки країни $\epsilon$ податкова політика держави. Від ефективності іiі функціонування буде залежати результат наповнення бюджетів різних рівнів. Фіскальна роль податкових надходжень туристичних підприємств відіграє важливу роль, проте підвищення iї результативності $\epsilon$ необхідним, адже фіскальна функція полягає у стягненні коштів у розпорядження держави та формуванні центральних фінансових ресурсів для забезпечення виконання функцій держави.

Дослідження окремих туристичних регіонів дасть змогу проаналізувати особливості здійснення фіскальної ролі податкових надходжень окремих туристичних підприємств, що дозволить застосувати напрямки удосконалення механізму оподаткування доходів туристичних підприємств 3 метою забезпечення наповнення бюджетів усіх рівнів. Ці питання i досі залишаються не розкриті, а тому потребують подальшого вивчення.

\section{ПЕРЕЛІК ВИКОРИСТАНИХ ДЖЕРЕЛ}

1. Власюк Н.І. Оцінювання фіскальної ефективності місцевого оподаткування / Н. І. Власюк // Науковий вісник НЛТУ України. - 2016. - Вип. 26.6. - С. 68-73. - Режим доступу: http://nbuv.gov.ua/UJRN/nvnltu_2016_26.6_13

2. Діденко А.В. Система оподаткування туристичного бізнесу в Україні. / А.В.Діденко // Економіка. Управління. Інновації. - 2010. - №1 (3). - с. 23-29.

3. Маліновська К.О. Фіскальна ефективність податку на доходи фізичних осіб та його роль у формуванні бюджетів різних рівнів [Електронний ресурс] / К. О. Маліновська, А. С. Гера // Вісник Житомирського національного агроекологічного університету. - 2011. - № 2(2). - С. 427-433. - Режим доступу: http://nbuv.gov.ua/UJRN/Vzhnau_2011_2(2)__50 
4. Момонт Т.В. Визначення алгоритму побудови фінансового, податкового та управлінського обліків на туристичних підприємствах України [Електронний ресурс] / Т.В. Момонт // Вісник [Київського інституту бізнесу та технологій]. - 2015. - Вип. 1. - С. 64-69. - Режим доступу: http://nbuv.gov.ua/UJRN/Vkib_2015_1_13

5. Офіційний сайт Міністерства економічного розвитку і торгівлі України [Електронний ресурс]. - Режим доступу: http://www.me.gov.ua

6. Податковий кодекс України від 02.12.2010 р. № 2755-VI [Електронний ресурс] - Режим доступу: http://zakon3.rada.gov.ua/laws/show/2755-17

7. Синявська Л.В. Фіскальна роль податків в Україні [Електронний ресурс] / Л. В. Синявська // Економічні науки. Сер. : Облік і фінанси. - 2012. - Вип. 9(3). - С. 276-282. - Режим доступу: http://nbuv.gov.ua/UJRN/ecnof_2012_9(3)__40

8. Снігир А.В. Особливості стратегічного менеджменту туристичного підприємства / А.В. Снігир // Вісник Хмельницького національного університету. - 2015. - № 4. - Т. 2. - С.66-69.

9. Томнюк Т. Л. Шляхи максимізації доходів держави від провадження туристичної діяльності / Т. Л. Томнюк // Облік і фінанси. - 2015. - № 1. - С. 114-119. - Режим доступу: http://nbuv.gov.ua/UJRN/Oif_apk_2015_1_19

\section{REFERENCES}

1. Vlasyuk, N.I. (2010). Otsinyuvannya fiskal'noyi efektyvnosti mistsevoho opodatkuvannya [Estimation of fiscal efficiency of local taxation] Naukovyy visnyk NLTU Ukrayiny - Scientific Bulletin of NLTU of Ukraine, 26.6. Retrieved from: http://nbuv.gov.ua/UJRN/nvnltu_2016_26.6_13

2. Didenko, A.V. (2010) Systema opodatkuvannya turystychnoho biznesu v Ukrayini [Taxation system of tourism business in Ukraine] Ekonomika. Upravlinnya. Innovatsiyi - Economy. Management. Innovations, 3 [in Ukrainian].

3. Malinovs'ka, K.O. (2011). Fiskal'na efektyvnist' podatku na dokhody fizychnykh osib ta yoho rol' u formuvanni byudzhetiv riznykh rivniv [The fiscal efficiency of the personal income tax and its role in shaping budgets of different levels] Visnyk Zhytomyrs'koho natsional'noho ahroekolohichnoho universytetu- Bulletin of Zhytomyr National Agroecological University, 2(2), 427-433. - Retrieved from: http://nbuv.gov.ua/UJRN/Vzhnau_2011_2(2)_50 [in Ukrainian].

4. Momont, T.V. (2015) Vyznachennya alhorytmu pobudovy finansovoho, podatkovoho ta upravlins'koho oblikiv na turystychnykh pidpryyemstvakh Ukrayiny [Definition of algorithm for construction of financial, tax and management accounts at tourist enterprises of Ukraine] Visnyk Kyyivs'koho instytutu biznesu ta tekhnolohiy - Bulletin of the Kiev Institute of Business and Technologies, 1, 64-69. Retrieved from: http://nbuv.gov.ua/UJRN/Vkib_2015_1_13 [in Ukrainian].

5. Ofitsiynyy sayt Ministerstva ekonomichnoho rozvytku i torhivli Ukrayiny [Official site of the Ministry of Economic Development and Trade of Ukraine]. me.gov.ua-Retrievedfrom: http://www.me.gov.ua[in Ukrainian].

6. Podatkovyy kodeks Ukrayiny 02.12.2010, 2755-VI [Tax Code of Ukraine] zakon3.rada.gov.ua.Retrieved from: http://zakon3.rada.gov.ua/laws/show/2755-17 [in Ukrainian].

7. Synyavs'ka, L.V. (2012) Fiskal'na rol' podatkiv v Ukrayini [Fiscal role of taxes in Ukraine] Ekonomichni nauky: Oblik $i$ finansy - Economic sciences: Accounting and Finance, 9(3), 276-282. Retrieved from: http://nbuv.gov.ua/UJRN/ecnof_2012_9(3)_40[in Ukrainian].

8. Snihyr, A.V. (2015) Osoblyvosti stratehichnoho menedzhmentu turystychnoho pidpryyemstva [Features of the strategic management of the tourist enterprise] Visnyk Khmel'nyts'koho natsional'noho universytetu -Bulletin of the Khmelnytsky National University, 4, 2, 66-69. [in Ukrainian].

9. Tomnyuk, T.L. (2015) Shlyakhy maksymizatsiyi dokhodiv derzhavy vid provadzhennya turystychnoyi diyal'nosti [Ways of maximizing state revenues from tourism activities]. Oblik i finansy-Accounting and finance, 1 , 114-119. Retrieved from: http://nbuv.gov.ua/UJRN/Oif_apk_2015_1 [in Ukrainian].

Одержано 02.03. 2018 p. 